\title{
Artikkeli
}

\section{Vaakakupissa vaarat ja vastuu Julkisen palvelun median arvot sosiaalisen median alustojen paineessa}

\begin{abstract}
Sosiaalisen median alustat ovat muovanneet media-alan prosesseja ja käytäntöjä merkittävästi. Alustayritysten toimintaa ohjaavat erilaiset arvot ja tavoitteet kuin mediaorganisaatioita, mikä aiheuttaa toimijoiden välille ristiriitaa. Toimintatavoistaan ja arvoistaan sosiaalisessa mediassa joutuvat neuvottelemaan erityisesti julkisen palvelun mediayhtiöt, joiden peruskivenä ovat julkisen palvelun arvot. Tarkastelemme tässä artikkelissa suomalaisen julkisen palvelun mediayhtiön Yleisradion alustasuhdetta laadullisen haastatteluaineiston avulla. Kysymme, miten Yleisradiossa kuvataan ja perustellaan suhdetta sosiaalisen median alustoihin ja minkälaiseen arvopuheeseen suhteen kuvaaminen kytkeytyy. Analyysimme perusteella Ylen alustasuhde näyttäytyy tasapainotteluna. Ylen toiminta sosiaalisen median alustoilla pohjautuu sen oman legitimiteetin varmistamisen lisäksi eettisyyteen ja vahvaan julkisen palvelun eetokseen. Arvopuheen osalta nousevat esiin ennen kaikkea universaaliuteen, riippumattomuuteen ja yhteiskunnan palvelemiseen liittyvät arvot. Alustasuhteen tasapainotteleva, neuvotteleva olemus korostuu niin puheessa kuin haastateltavien kuvaamissa työkäytännöissä. Alustat eivät vain yksipuolisesti muuta media-alan prosesseja, vaan osin myös olemassaolollaan ohjaavat arvopohjaiseen keskusteluun ja pohdintaan.
\end{abstract}

AVAINSANAT: Sosiaalinen media, alustaistuminen, julkisen palvelun media, yleisradioyhtiöt, arvopuhe

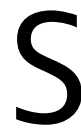
osiaalisen median alustat muovaavat yhä vahvemmin sekä mediaorganisaatioiden tuotanto- ja jakeluprosesseja että yleisöjen mediankulutustottumuksia (Rashidian ym. 2019; Hokka 2017; Newman 2020). Julkisen palvelun medioille tämä tarkoittaa pyrkimystä aiempaa vahvempaan läsnäoloon sosiaalisessa mediassa, jonka kautta ne yrittävät saavuttaa erityisesti nuoria ja muita vaikeasti tavoitettavia yleisöjä (Sehl, Cornia ja Nielsen 2018, 13; Schulz, Levy ja Nielsen 2019). Julkisen palvelun median ja alustojen suhde on kuitenkin jännitteinen: toimijoiden erilaiset arvot ja tavoitteet luovat niiden välille ristiriitoja (esim. Nikunen ja Hokka 2020). 
Tässä artikkelissa tarkastelemme, miten julkisen palvelun media näkee roolinsa sosiaalisen median alustojen toimintalogiikan hallitsemassa toimintaympäristössä ja analysoimme, millaiseen arvopuheeseen alustasuhteen kuvaaminen kytkeytyy. Tutkimuskohteemme on suomalainen julkisen palvelun media Yleisradio. Yhtiö linjaa strategiassaan hyödyntävänsä sosiaalisen median alustoja "harkiten silloin, jos tavoitamme siellä yleisöjä, joita emme Ylen alustoilta tavoita" (Yle 2020). Sosiaalisen median hyödyntäminen kytkeytyy erityisesti nuorten yleisöjen tavoittamiseen, mikä näyttäytyy Yleisradion strategiassa tavoitteena ymmärtää eri-ikäisten yleisöjen mediankäyttöä aiempaa perusteellisemmin.

Organisaationa Yleisradion toimintaa ohjaavat sen arvot, joita tuotetaan ja uusinnetaan jatkuvasti arvopuheen ja arvokäytänteiden kautta organisaation arjessa (Gehman, Treviño ja Garud 2013; Meyer 1995). Yleisemmin julkisen palvelun median toimintaa ohjaavat julkisen palvelun arvot (esim. Lowe 2010, 25-26), joista yhtenä tärkeimmistä on pidetty universaalia palvelua, joka mahdollistaa tilan julkiselle keskustelulle (Debrett 2010, 187; Born ja Prosser 2001, 671). Sosiaalisen median hyödyntäminen voi tukea tätä tavoitetta mutta herättää samalla kysymyksiä julkisen palvelun toiminnan riippumattomuudesta, jos sisältöjä levitetään alustojen ehdoilla.

Sosiaalisessa mediassa toimiessaan julkisen palvelun media joutuukin sopeutumaan alustojen toimintalogiikkaan ja neuvottelemaan alustasuhteeseen liittyvistä arvoista (Bolin 2011). Käyttäjien tuottamiin datajälkiin perustuva analytiikka, algoritmit ja automaattinen personointi vaikuttavat alustoilla julkaistavien sisältöjen sekä toimijoiden näkyvyyteen ja saavutettavuuteen (Van Dijck, Poell ja de Waal 2018; Just ja Latzer 2017). Lisäksi alustaistumisen ja dataistumisen (esim. Van Dijck, Poell ja de Waal 2018; Caplan ja boyd 2018) on nähty vaikuttavan julkisen palvelun median prosesseihin muuttamalla sisällöntuotantoa käyttäjäkeskeisempään suuntaan (Hokka 2017, 235). Nämä prosessit haastavat julkisen palvelun arvoja ja ovat pakottaneet julkisen palvelun mediat pohtimaan alustasuhdettaan kriittisesti.

Tässä artikkelissa kysymme 1) miten Yleisradiossa kuvataan ja perustellaan suhdetta sosiaalisen median alustoihin ja 2) minkälaiseen arvopuheeseen suhteen kuvaaminen kytkeytyy. Tutkimuksen aineistona on kymmenen Yleisradion työntekijän haastattelut. He vastaavat Yleisradion eri osastojen sosiaalisen median suunnittelusta ja ovat osa Yleisradion sisäistä sosiaalisen median kehittäjäverkostoa. Empiirinen tutkimuksemme ottaa osaa keskusteluun julkisen palvelun median alustaistumisesta ja dataistumisesta, joita on tähän mennessä käsitelty tutkimuskirjallisuudessa lähinnä teoreettisella tasolla (ks. esim. Nikunen ja Hokka 2020; Caplan ja boyd 2018), joitakin poikkeuksia lukuun ottamatta (esim. Hokka 2017; Nielsen ja Ganter 2018). Lisäksi tarkastelemme mediaorganisaation arvoja erityisesti organisaation toimintaan liittyvien ja sen jäsenten keskuudessa vallitsevien arvojen pohjalta.

Analyysimme osoittaa, että Yleisradion suhde sosiaalisen median alustoihin tiivistyy tasapainottelun tematiikkaan, jossa keskiössä on toisaalta mahdollisimman suuren yleisön saavuttaminen sosiaalisen median avulla ja toisaalta samaisen yleisön ohjaaminen Yleisradion omien alustojen pariin. Arvopuheen kannalta tasapainottelu kilpistyy kolmeen arvoon: universaaliuteen, riippumattomuuteen ja yhteiskunnan palvelemiseen. Kaiken kaikkiaan tuloksemme osoittavat, että yleisradioyhtiössä tiedostetaan alustaistumisen haasteet ja käydään aktiivista dialogia sisältöjen tuotanto- ja jakeluprosessien muutoksesta. 


\section{Median alustaistuminen ja dataistuminen}

Sosiaalisen median alustat ovat teknologisia infrastruktuureja, jotka samanaikaisesti mahdollistavat käyttäjien välisen vuorovaikutuksen ja muovaavat sosiaalisia toimintoja (esim. Plantin ja Punathambekar 2019; Laaksonen 2020). Van Dijckin, Poellin ja de Waalin $(2018,4)$ määritelmän mukaan alustat ovat ohjelmoituja digitaalisia arkkitehtuureja, jotka on suunniteltu järjestelemään niin yksittäisten käyttäjien kuin yritys- ja julkisyhteisöjenkin välistä vuorovaikutusta ja joiden toiminta perustuu pitkälti käyttäjistä saatavan datan systemaattiseen keräämiseen, algoritmiseen käsittelyyn, levittämiseen ja kaupallistamiseen. Yksittäiset alustat eivät ole toisistaan erillisiä, vaan ne toimivat verkkoympäristössä suhteessa toisiinsa osana niin sanottua alustaekosysteemiä (Van Dijck 2013, 21).

Nieborgin ja Poellin (2018) mukaan alustaistumisella (platformization) tarkoitetaan sitä, miten digitaalisten alustojen vaikutus muovaa erilaisten kulttuurisisältöjen tuotantoa, jakelua ja levitystä. Alustaistumisella viitataankin siihen, miten kokonaiset toimialat muuttuvat alustojen vaikutuksen myötä (Helmond 2015). Laajemmin tarkasteltuna alustaistumisella voidaan viitata sosiaalisen median alustojen leviämiseen ja pyrkimykseen tehdä verkossa olevista sisällöistä alustojen mukaisia sekä alustoista verkon hallitsevia infrastruktuureja (Gillespie 2010). Dataistuminen puolestaan viittaa siihen, miten erilaisia sosiaalisia toimintoja ja suhteita muutetaan dataksi: numeerisesti mitattavaan ja käsiteltävään muotoon (esim. Van Dijck ja Poell 2013, 9). Median kontekstissa tämä tarkoittaa esimerkiksi yhä tarkempaa ja yksityiskohtaisempaa dataa siitä, miten yleisöt eri sisältöjä käyttävät. Sosiaalisen median kontekstissa dataistuminen on kuitenkin alisteista alustaistumiselle: kun sisältöjä tehdään sosiaaliseen mediaan, datan tarjoavat ja sen muodon määrittelevät sosiaalisen median alustat.

Media-alan alustaistuminen ei ole pelkästään alan ulkoinen prosessi, vaan siihen vaikuttaa myös mediateollisuus itse (Nieborg ja Poell 2018, 4287). Nielsenin ja Ganterin $(2018,1614)$ mukaan esimerkiksi verkossa muutenkin vahvasti menestyvät uutismediat mukautuvat alustojen muutoksiin yleisöjen menettämisen pelossa. Monet niin sanotut diginatiivit mediat, kuten BuzzFeed, ovat suunnitelleet tuotanto- ja levitysprosessinsa pitkälti sosiaalisen median alustojen ehdoilla, kun taas monet perinteiset mediat pyrkivät tasapainottelemaan alustoihin sopeutumisen ja autonomian säilyttämisen välillä (Van Dijck, Poell ja de Waal 2018,67).

Alustaistuminen on muuttanut mediatyön (Deuze 2007; Malmelin ja Villi 2017) prosesseja ja sisältöjä. Vaikutukset ovat nähtävissä esimerkiksi journalistisessa työssä, sillä alustaistumisen seurauksena alustat muovaavat sekä journalistisia prosesseja että toimituksissa tehtäviä sisältöjä (esim. Nieborg ja Poell 2019; Meese ja Hurcombe 2020; Caplan ja boyd 2018). Tämän on jossain määrin nähty johtavan alustojen ylivaltaan mediaorganisaatioiden yrittäessä sopeuttaa toimintaansa alustojen toimintamekanismien mukaiseksi, esimerkiksi maksimoidakseen sisältöjensä leviämisen (Rashidian ym. 2019). Yksi näkyvimmistä alustaistumisen tuomista muutoksista onkin datan ja analytiikan laaja hyödyntäminen mediaorganisaatioissa (Hanusch 2016). Katsoja- ja lukijamäärien lisäksi erilaiset analytiikkatyökalut keräävät dataa sosiaalisen median alustoilta tarjoten mediataloille tietoa siitä, miten heidän sisältönsä leviävät alustaekosysteemissä (esim. Neheli 2018). 
Perinteisesti toimituksissa tehdyt valinnat esimerkiksi uutisaiheiden suhteen ovat perustuneet oletukseen, että toimittajat tietävät, mitä yleisön pitäisi tietää. Analytiikka vaikuttaa kuitenkin portinvartijuuden prosesseihin luomalla uusia rutiineja ja muokkaamalla vanhoja (Hanusch 2016, 1582), kun sen avulla tehdään päätöksiä sisällöistä tai tuotetaan kohdennettuja julkaisuja käyttäjille. Aiemmin toimittajat ovat myös vastanneet esimerkiksi uutissisältöjen arvottamisesta uutiskriteerien perusteella, mutta sosiaalisessa mediassa sisältöjen näkyvyys on merkittävissä määrin alustojen algoritmien varassa (esim. Hermida 2020). Toisaalta myös suhtautuminen analytiikkaa kohtaan on muuttunut. Siinä missä aiemmin analytiikkaan suhtauduttiin skeptisesti, nykyään mediataloissa kaivataan verkkoanalytiikkaa työn tueksi, jotta yleisöt tavoitetaan mahdollisimman hyvin (Hanusch 2016, 3-4; Cherubini ja Nielsen 2016, 7; Zamith 2018, 419).

\section{Sosiaalinen media julkisen palvelun työkaluna}

Julkisen palvelun medioilla on ollut vuosikymmenien ajan vahva asema monissa Euroopan maissa. Verkossa ne kuitenkin kilpailevat yleisön ajasta niin kansainvälisten medioiden, suoratoistopalveluiden kuin lukuisten sosiaalisen median alustojen kanssa. Lisäksi kansallisilla markkinoilla yleisradioyhtiöillä ovat vastassaan myös kaupalliset mediat, mikä on viime vuosina konkretisoitunut kaupallisen puolen edustajien pyrkimyksinä rajoittaa julkisen palvelun median toimintaa esimerkiksi lainsäädännön kautta (ks. esim. Sehl, Fletcher ja Picard 2020; Freedman ja Goblott 2018; Hölig ja Hasebrink 2018). Vastaava kehityskulku on nähtävissä myös Suomessa, jossa Yleisradion verkossa tapahtuvaa tekstimuotoista julkaisutoimintaa ollaan tämän artikkelin kirjoitushetkellä rajaamassa media-alan työnantajien etujärjestön Medialiiton Euroopan komissiolle tekemän kantelun seurauksena.

Suomessa Yleisradion jokseenkin vahvasta asemasta nykypäivänä kielii se, että suomalaiset pitävät Yleisradiota maan luotettavimpana uutismediana ja Ylen verkkomedia on kolmanneksi suosituin heti molempien iltapäivälehtien jälkeen (Reunanen 2020, 30, 14). Yleisradiota pidetään brittiläisen BBC:n ohella edelläkävijänä verkkostrategiansa suhteen (Rotermund 2018, 81; Sehl, Cornia \& Nielsen 2016, 39). Yleisesti yleisradioyhtiöissä nähdään, että niiden vakiintunut maine, vahva brändi, sekä laaja ja lojaali yleisö helpottavat niiden sopeutumista digitaaliseen toimintaympäristöön. Digitaalisten strategioiden kehitystyölle voidaan myös nähdä olevan yleisradioyhtiöissä vähemmän taloudellista painetta ja enemmän resursseja kuin kaupallisissa mediataloissa, sillä lupamaksuihin tai verotukseen perustuvan rahoitusmallin vuoksi yhtiöiden ei tarvitse kehitystyössä keskittyä erityisesti rahallisten tuottojen kasvattamiseen (Sehl, Cornia ja Nielsen 2016, 10). Toisaalta tutkimuksessa on myös huomattu, että yhtiöiden verkkostrategioista puuttuu usein johdonmukaisuus, eikä eri osastojen ja brändien toiminta ole yhtenäistä (Donders 2019, 1024). Haasteena onkin muuttaa broadcast-sisältöjen tuotantoa varten rakennetut organisaatiot digiympäristöön sopivaan tuotantoon soveltuviksi (Sehl, Cornia ja Nielsen 2019).

Sosiaalisen median myötä yleisradioyhtiöiden jakelukanavat ja yleisösuhde ovat muuttuneet merkittävästi (Sehl, Cornia ja Nielsen 2018). Alustojen hyödyntäminen ohjaa yleisradioyhtiöiden toimintaa perinteisestä joukkoviestinnästä vuorovaikutteisempaan 
suuntaan (Keinonen ja Shagrir 2017, 65; Iosifidis 2011, 631-632). Yleisön osallistamisella ja aktivoimisella verkossa voidaankin nähdä olevan selkeitä strategisia perusteita, joilla tähdätään yleisradioyhtiöiden aseman vankistamiseen. Kaupallisen median kohdalla yleisön sitoutuminen lisää lojaaliutta mediabrändiä kohtaan, jolloin satunnaisista kuluttajista voi tulla uskollisia, maksavia asiakkaita (Lawrence, Radcliffe ja Schmidt 2018, 17-18). Yleisradioyhtiöt voivat puolestaan yleisöä sitouttamalla ja laajentamalla vahvistaa institutionaalista legitimiteettiään, mikä osaltaan perustelee niiden rahoitusmallia (Enli 2008, 109, 117).

Käytännön työssä suomalaiset mediaorganisaatiot näkevät sosiaalisen median erityisesti välineenä, jonka kautta seurataan kansalaiskeskustelua, etsitään ajankohtaisia juttuaiheita, pidetään yhteyttä yleisöön ja saadaan palautetta (Juntunen 2017, 17). Eurooppalaisissa yleisradioyhtiöissä erityisesti Facebookia pidetään merkittävänä, koska sillä on laaja käyttäjäkunta ja siten mahdollisuus monipuolisten yleisöjen tavoittamiseen on suuri (Sehl, Cornia ja Nielsen 2018, 15). Norjan yleisradioyhtiö NRK:n Facebookin käyttöä tarkastelleen Moen $(2013,120)$ mukaan yleisradioyhtiöiden sosiaalisen median käyttö onkin kehittynyt samaan tapaan kuin muiden verkkopalveluiden käyttöönotto: käytännöt ovat kehittyneet alkuvaiheen yksittäisistä kokeiluista kohti vakiintuneempaa toimintaa, ja alustojen kehittyessä niiden käyttöä on yhdenmukaistettu luomalla muun muassa sosiaalisen median strategioita.

Oxfordin yliopiston Reuters-instituutin selvityksen (Sehl, Cornia ja Nielsen 2018, 28-30) mukaan alustaistumisen ongelmia pohditaan yleisradioyhtiöissä aktiivisesti. Medioissa seurataan tarkkaan alustojen ja niiden algoritmien kehitystä, minkä perusteella tehdään johtopäätöksiä siitä, miten mediat voivat käyttää alustoja tehokkaasti tavoittaakseen kohdeyleisönsä. Sehlin ja kumppaneiden (emt. 27) mukaan yleisradioyhtiöt ovat myös painottaneet, että vaikka analytiikkaa seurataan tarkasti ja se voi auttaa esimerkiksi julkaisupäätösten tekemisessä, ovat päätökset silti loppujen lopuksi toimituksellisia, eivätkä analytiikka ja näin ollen alustat määritä yhtiöiden strategiaa. Mediayhtiöt siis vaikuttavat aktiivisesti toimivan alustaistumista ja dataistumista vastaan pitämällä kiinni vanhoista periaatteista ja arvoista. Tämä on kiinnostavaa artikkelin tutkimusongelman kannalta: Miten julkisen palvelun media näkee roolinsa sosiaalisen median alustojen toimintalogiikan hallitsemassa toimintaympäristössä ja millaiseen arvopuheeseen alustasuhteen kuvaaminen kytkeytyy?

\section{Arvot julkisen palvelun mediayhtiössä}

Organisaation arvot käsitetään osana organisaation kirjoittamatonta kulttuuria eli sitä symbolista merkitysjärjestelmää, jossa organisaatiossa eletään (Schein 1985). Usein arvot ovat myös kirjoitettu dokumentti, joka on johdon määrittelemä tai johon on strategiaprosessin osana pyritty tiivistämään organisaation kulttuuria. Organisaation arjessa arvoja jalkautetaan ja työstetään eri tavoin toimintojen ja diskurssien kautta arvokäytänteissä (Gehman, Treviño ja Garud 2013, 86-87). Tutkimukset kuitenkin osoittavat, että käytännössä organisaation arvot eivät ole yksiselitteisiä tai ylhäältä päin määriteltyjä, vaan niistä neuvotellaan jatkuvasti puheessa ja käytänteissä, ja esimerkiksi työntekijöiden 
omien arvojen vaikutus organisaation arvoihin voi olla merkittävä (Bourne ja Jenkins 2013, 504-507). Tyypillisesti organisaatiossa on kuitenkin jonkinlainen käsitys siitä, mitä ovat organisaation jaetut arvot, ja niistä viestitään organisaation sisällä eri tavoin (Pruzan 2001, 272, 276; Bourne ja Jenkins 2013, 500-501).

Arvot ovat läsnä organisaation sisällä myös arvopuheena (Gehman, Treviño ja Garud 2013, 104-105; Meyer 1995). Arvopuhe on tyypillisesti abstraktia ja sen tarkoituksena on edistää organisaation pyrkimyksiä (vrt. Christensen ym. 2020); sillä ei välttämättä ole mitään kytköksiä käytäntöihin tai toimintaan, vaan puheen avulla viestitään ja luodaan intentioita ja toiveita. Tällainen puhe voi kuitenkin olla performatiivista diskursiivista toimintaa, eli se muokkaa ja rakentaa organisaatiota ja sen todellisuutta (Gond ym. 2016; Gehman, Treviño ja Garud 2013, 104-105). On esimerkiksi osoitettu, että organisaation arvojen kanssa linjassa olevat asiat koetaan strategisesti tärkeiksi (Bansal 2003, 522). Organisaation jäsenten tuottama arvopuhe ja kertomukset tuovat siis organisaation arvoja näkyväksi mutta myös osallistuvat arvoista käytävään neuvotteluun (Meyer 1995, 218-219).

Julkisen palvelun mediayhtiössä organisaation arvojen voidaan nähdä kietoutuvan julkisen palvelun median arvoihin, joihin kuuluvat muun muassa universaali ja kattava, yhtäläisesti kaikkien saatavilla oleva palvelu, riippumattomuus, korkea laatu, vastuullisuus, innovatiivisuus sekä yhteiskunnan tarpeiden tyydyttäminen (esim. Lowe 2010, 26; EBU 2012). Lowen $(2010,25)$ mukaan "julkisen palvelun medialla on tehtävä palvella kansalaisyhteiskuntaa edistämällä totuutta, oikeudenmukaisuutta, tasa-arvoa ja kansalaisten oikeuksia. Toiminta tähtää kattavuuteen, eli kaikkien kansalaisten palvelemiseen yhtäläisin ehdoin". Yleisradio on sitoutunut Euroopan yleisradiounionin EBU:n keskeisiin arvoihin, ja julkisen palvelun periaatteet ovatkin vahvasti läsnä yhtiön strategiassa. Strategian mukaisesti Ylen missiona on vahvistaa suomalaista yhteiskuntaa ja kulttuuria (Yle 2017; Yle 2020). Demokratian tukeminen on puolestaan keskiössä Yleisradion toiminnasta määräävässä laissa Yleisradio Oy:stä (19.8.2005/635, 7 §), jossa erikseen mainitaan julkisen palvelun ohjelmatoiminnan tehtäviksi tukea kansanvaltaa ja jokaisen osallistumismahdollisuuksia siihen, kehittää ja tukea kotimaista kulttuuria sekä huomioida kansalaisten sivistäminen.

Julkisen palvelun mediaa koskeva kansainvälinen tutkimus korostaa erityisesti universaaliuden arvoa, jota on perinteisesti jäsennetty tutkimuskirjallisuudessa sekä sisältöjen saavutettavuuden että niiden monimuotoisuuden kannalta (Nikunen ja Hokka 2020, 2). Debrettin $(2010,187)$ mukaan universaaliutta pidetään keskeisimpänä arvona, koska sisältöjen yhtäläinen saavutettavuus mahdollistaa laajojen yleisöjen tavoittamisen ja luo siten tilaa julkiselle keskustelulle. Julkisen keskustelun käymistä taas pidetään yleisesti edellytyksenä demokratian toteutumiselle.

Digitalisaation seurauksena universaalius on kuitenkin arvona saanut uusia muotoja (van den Bulck ja Moe 2018, 890). Tutkimuskirjallisuudessa universaaliuden asemaa datankeruun ja personointialgoritmien hallitsemassa mediaympäristössä on lähestytty kahdesta näkökulmasta: toiset näkevät datafikaation ja lisääntyvän sisältöjen personoinnin uhkana universaaliuden toteutumiselle (Born 2004), kun taas toiset näkevät samojen kehityskulkujen täydentävän universaalin palvelun jo ennestään yleisöille tarjoamien palvelujen ja sisältöjen kirjoa personoiduilla tuotteilla (Jakubowicz 2006; ks. myös Helberger 2019). Jäl- 
kimmäistä näkökulmaa on kutsuttu "uudeksi universaaliudeksi" (Debrett 2010, 187; Iosifidis 2011). Hokka (2019) käyttää myös käsitettä "vivahteikas universaalius” (nuanced universality), jolla hän viittaa siihen, miten eri käyttäjäryhmien tavat kuluttaa mediaa pitää ottaa aiempaa tarkemmin huomioon sisältöjä tuotettaessa ja jaettaessa. Yleisön segmentoinnin avulla voidaan parantaa saavutettavuutta ja tavoittavuutta sekä sisältöjen että käytettyjen kanavien osalta. Saavutettavuus käsitetään universaaliuden ideaalin mukaisesti niin, että median tuottama sisältö on yleisön saavutettavissa esimerkiksi verkkosivujen kautta ilman alustojen väliintuloa. Tavoittavuus puolestaan viittaa siihen, miten median tuottama sisältö tavoittaa kohderyhmän algoritmien hallitsemassa alustaekosysteemissä.

"Uuden universaaliuden" voidaan nähdä vetoavan julkisen palvelun mediayhtiöihin erityisesti niiden sisältöjen monimuotoisuuteen liittyvien arvojen kannalta, sillä personoinnilla voidaan esimerkiksi vastata vähemmistöille suunnattujen sisältöjen tuotannon ja jakelun haasteisiin. Van den Bulck ja Moe $(2018,890)$ toteavatkin flaamilaista julkisen palvelun mediaa VRT:tä ja norjalaista NRK:ta käsittelevässä tutkimuksessaan, että personointi on tullut jäädäkseen yleisradioyhtiöiden toimintatapoihin. Algoritmeihin ja käyttäjistä kerättävään dataan pohjautuva personointi nähtiin molemmissa organisaatioissa nimenomaan tapana toteuttaa "uutta universaaliutta". On huomattava, että vaikka sisällöt olisivatkin tarjolla yleisradioyhtiöiden omilla kanavilla ja alustoilla, niin yleisö ei välttämättä niitä sieltä löydä - siksi tavoittavuus on nykyisessä yltäkylläisessä mediamaisemassa usein yhtä olennaista kuin saavutettavuus.

Uusi universaalius siis ainakin näennäisesti kohentaa sisältöjen monimuotoisuutta ja saavutettavuutta, mutta sen on nähty myös keskittyvän liikaa yksilön tarpeiden palvelemiseen (Nikunen ja Hokka 2020, 4-5; Enli 2008, 108). Nikunen ja Hokka $(2020,8)$ huomauttavat, että tällaisen kehityskulun myötä julkisen palvelun mediayhtiöt ovat ottaneet askeleen kauemmas yhteistä julkista tilaa luovasta perinteisestä roolistaan. Kiinnostavaa siis onkin, kuinka pitkälle personoituun tarjontaan yleisradioyhtiö voi sukeltaa, kunnes se menettää julkisen palvelun luonteensa (vrt. Helberger 2019).

Toisaalta julkisen palvelun arvojen voidaan nähdä perustelevan vahvaa läsnäoloa sosiaalisessa mediassa, sillä sen kautta on mahdollista vastata tehokkaasti kansalaisten nykyaikaisiin tapoihin viestiä ja kuluttaa mediaa sekä näkökulmasta riippuen toteuttaa universaaliuden arvoa. Alustoilla operoimiseen liittyy kuitenkin myös systeemisiä haasteita. Moen $(2013,115)$ mukaan yleisradioyhtiöt voidaan nähdä epäkaupallisina toimijoina, jotka astuvat globaalien kaupallisten yhtiöiden alueelle hyödyntäessään sosiaalisen median alustoja toiminnassaan. Suomessa Yleä onkin kritisoitu siitä, että se käyttää kaupallisia sosiaalisen median alustoja julkisin varoin tuotettujen sisältöjen markkinointiin (Keinonen 2015, 68). Yleisradiossa kaupallisten alustojen käyttö on kuitenkin nähty välttämättömyytenä (emt.). Samalla voidaan pohtia, toteutuuko yleisradiotoiminnan riippumattomuus, jos sisältöjä levitetään sosiaalisen median alustojen ehdoilla (vrt. Helberger 2020). Riskinä on julkisen palvelun mediayhtiöiden joutuminen alustayhtiöiden luomien "superstruktuurien" armoille (Andersson Schwarz 2017; Laaksonen 2020). Viestinnän infrastruktuurina toimivat sosiaalisen median yhtiöt (esim. Facebook ja Twitter) tai käyttöjärjestelmävalmistajat (Apple, Google) voivat halutessaan omavaltaisilla päätöksillä estää tiettyjen verkkopalveluiden käytön. Julkisen palvelun median ja kaupallisten alustojen suhdetta määrittelevät siis makrotasolla vastuullisuuden, hyödyllisyyden ja välttämättömyyden kysymykset. 


\section{Aineisto ja menetelmät}

Tutkimuksen aineisto on kerätty osana laajempaa tutkimusprojektia, jossa havainnoinnin ja haastattelujen keinoin tutkittiin mediaorganisaatioiden innovaatiokäytänteitä. Tutkimusaineisto koostuu kymmenestä puolistrukturoidusta teemahaastattelusta, jotka teki valtaosin artikkelin toinen kirjoittaja. Haastateltavina on kymmenen Yleisradion työntekijää, jotka ovat osa Ylen sisäistä sosiaalisen median kehittämisverkostoa, jossa jaetaan tietoa eri sosiaalisen median alustojen käytöstä ja kehitetään läsnäoloa eri kanavissa. Haastateltavien hankkimiseen käytettiin lumipallo-otantaa, jossa lisähaastateltavia etsittiin edellisten haastateltavien avulla (Tuomi ja Sarajärvi 2009, 86). Haastateltavia pyydettiin nimeämään verkostoon kuuluvia jäseniä, joilla olisi relevanttia sanottavaa haastatteluiden teemoihin liittyen.

Haastateltavat ovat iältään 29-55-vuotiaita, ja heillä on kokemusta media-alalta noin 10-30 vuotta. Haastattelujen tekohetkellä haastateltavilla oli ollut työkokemusta Yleisradiossa noin vuodesta yli kahteenkymmeneen vuotta. Haastateltavat työskentelevät Yleisradion eri osastoilla, kuten uutis- ja ajankohtaistoiminnassa, luovissa sisällöissä sekä asiakkuus- ja kehitysyksikössä. Sosiaalinen media on vahvasti läsnä kaikkien haastateltavien päivittäisessä työssä. Kaikkien haastateltavien työtehtäviin kuuluu sosiaalisen median pidemmän aikavälin suunnittelu, ja osa myös päivittää itse sosiaalisen median tilejä. Tämän artikkelin aineistolainauksissa haastateltavien nimet ja työtehtävät sekä Yleisradion oma alusta, jolle haastateltava pääasiassa tuottaa sisältöä, on jätetty mainitsematta haastateltavien anonymiteetin säilyttämiseksi. Ylen omista alustoista haastateltavat tuottivat sisältöjä esimerkiksi Yle. fi-sivustolle, Uutisvahti-sovellukseen sekä Yle Areenaan.

Haastattelut suoritettiin touko-elokuussa 2019 ja niiden kesto oli 38-96 minuuttia. Haastatteluista yksi on tehty kasvotusten ja muut etäyhteyden välityksellä. Haastattelut toteutettiin puolistrukturoituina teemahaastatteluina, joten kaikissa haastatteluissa oli käytössä sama kysymysrunko, josta on tilanteen mukaan voitu poiketa, ja haastateltavat saivat vastata kysymyksiin omin sanoin haluamallaan tavalla (Eskola ja Suoranta 1998, 87). Teemat käsittelivät luovuutta, innovaatioita, sosiaalista mediaa, viestintäteknologiaa, journalistisen työnteon tapoja sekä tulevaisuuden näkymiä. Lisäksi haastateltavilta kysyttiin taustatietoja muun muassa heidän työkokemuksestaan. Tämän tutkimuksen kannalta oleellisia aihepiirejä ovat sosiaalista mediaa ja tulevaisuutta käsittelevät haastatteluteemat.

Seuraamme tässä tutkimuksessa Meyerin (1995) esittämää ajatusta siitä, että organisaation arvot esiintyvät, niitä uusinnetaan ja niitä voidaan tutkia organisaation jäsenten esittämien kertomusten ja puheen kautta. Tästä syystä tutkimusongelmamme kannalta kiinnostavaa on sellainen puhe, jossa haastateltavat kertovat kokemuksistaan sosiaalisen median alustojen työkäytöstä, toiveista ja tavoitteista niiden suhteen, ja jossa he suoraan pohtivat Yleisradion suhdetta alustayrityksiin. Näin ollen kiinnostuksemme ei kohdistu pelkästään niihin käytänteisiin, joilla Yleisradio vastaa tai sopeutuu alustaistumisen paineisiin, vaan myös niihin arvolatautuneisiin puhetapoihin, joilla näistä käytänteistä ja intentioista puhutaan.

Analyysia varten aineisto litteroitiin ja ladattiin Atlas.ti-ohjelmistoon. Litteraatteja oli yhteensä 122 liuskaa. Analyysimenetelmänä käytettiin laadullista sisällönanalyysiä, tarkemmin sanottuna teemoittelua, jossa aineistoa pilkotaan ja luokitellaan eri aihepiirien mukaan (Tuomi ja Sarajärvi 2009, 93). Analyysissa käytettiin iteratiivista lähestymistapaa, jossa analyysi vuorottelee aineistosta nousevien uusien tietojen ja olemassa olevien mallien, teorioi- 
den ja selitysten käytön välillä (Tracy 2013, 184). Iteratiivisessa mallissa tutkija palaa aineiston pariin kerta toisensa jälkeen, kun uusia kysymyksiä tai oivalluksia herää ja aiemmin tiedettyyn tietoon syntyy yhteyksiä.

Analyysi eteni vaiheittain. Ensimmäinen koodauskerta keskittyi siihen, mitä aineistossa esiintyy (ks. Tracy 2013, 189). Analyysin ensimmäisellä kierroksella ensimmäinen kirjoittaja luki läpi kaikki kymmenen litteroitua haastattelua ja merkitsi niihin tutkimuskysymysten kannalta olennaisia kohtia: sellaisia, joissa puhuttiin Ylen sosiaalisen median käytöstä, alustojen välisestä suhteesta, sosiaalisesta mediasta saatavasta analytiikasta ja alustojen tulevaisuudesta. Ensimmäisen koodauskerran jälkeen Atlas.ti:n hermeneuttisessa yksikössä oli 28 koodia, joista seitsemän liittyi alustojen väliseen suhteeseen, seitsemän sosiaalisesta mediasta saatavaan analytiikkaan, kymmenen Ylen sosiaalisen median käyttöön ja neljä tulevaisuuteen.

Analyysin toisessa vaiheessa koodeittain järjestetty aineisto luettiin lukuisia kertoja läpi uudestaan ja sitä teemoiteltiin laajempiin, abstrakteihin teemoihin etsimällä tekstipätkistä yhteneväisyyksiä. Samalla iteratiivisen prosessin mukaisesti tehtyjä havaintoja tulkittiin tutkimuskirjallisuuden ja tutkimusongelman kautta keskittyen median alustaistumiseen: siihen, miten haastateltavat kuvaavat ja pohtivat Yleisradion ja alustojen suhdetta yleisellä tasolla ja toisaalta käytäntöjen kautta. Kiinnostus sekä abstraktiin puheeseen että käytäntöihin näkyy sekä median alustaistumista koskevassa aiemmassa tutkimuksessa (Sehl, Cornia ja Nielsen 2018; van den Bulck ja Moe 2018) että organisaatioiden arvoja käsittelevässä kirjallisuudessa (esim. Meyer 1995; Christensen ym. 2020). Analyysin toisen vaiheen perusteella muodostui kuusi teemaa, jotka olivat neljäs julkaisukanava, sosiaalisen median hyödyntäminen, analytiikka ohjaavana tekijänä, natiivisisällöt vs. oma alusta, vaarat vs. Ylen vastuu ja epävarma tulevaisuus (ks. Taulukko 1). Kaikissa teemoissa korostui ajatus siitä, miten sosiaalisen median alustojen käyttötapoja neuvotellaan jatkuvasti käytäntöjen ja sisäisen keskustelun kautta. Päädyimme kuvaamaan tätä tasapainotteluna Ylen alustasuhteessa ja alustaistumisessa.

Analyysin kolmannessa vaiheessa tarkastelimme alustasuhdetta kuvaavaa puhetta erityisesti julkisen palvelun median arvojen ja arvopuheen näkökulmasta. Kävimme läpi teemoiteltua aineistoa uudelleen ja tarkastelimme kunkin teeman osalta, minkälaisiin kirjallisuudessa tunnistettuihin julkisen palvelun median arvoihin (esim. Lowe 2010, 25-26; EBU 2012) haastateltujen puhe kytkeytyy. Haastatteluissa ei kysytty suoraan arvoista, eli julkisen palvelun median arvot tulivat esille epäsuorasti silloin, kun haastateltavat perustelivat omaa tai Yleisradion toimintaa tai pohtivat Yleisradion suhdetta sosiaalisen median alustoihin. Siksi analyysin toisessa vaiheessa seurasimme Christensen ja kumppanien (2020) ajatusta arvopuheesta intentioita ja toiveita luovana puheena ja kiinnitimme huomiomme niihin tavoitteisiin ja toiveisiin, joilla haastatellut perustelivat Yleisradion toimintaa sosiaalisessa mediassa. Seuraavaksi yhdistimme näitä teemoissa esiintyviä intentioita ja tavoitteita kirjallisuudessa esitettyihin julkisen palvelun median arvoihin (ks. Taulukko 1). Esimerkiksi universaalius kytkeytyi haastateltavien puheessa toiveisiin tavoittaa yleisöjä laajasti, vastuullisuus ja riippumattomuus puolestaan liittyivät pyrkimykseen mahdollistaa Yleisradion sisältöjen käyttö myös ilman sosiaalista mediaa. Vastaavasti esimerkiksi kansalaisyhteiskunnan tukeminen ja palveleminen esiintyivät erityisesti puheena asemoida Yleisradio totuuden ja faktapohjaisuuden edistäjäksi tai tasapainottavaksi tekijäksi verkon areenoilla. 
Taulukko 1. Aineiston teemojen yhteys arvopuheeseen.

\begin{tabular}{|c|c|c|}
\hline Aineiston teemat & $\begin{array}{l}\text { Teemaan kytkeytyvät tavoitteet ja } \\
\text { toimintavat }\end{array}$ & Julkisen palvelun median arvot \\
\hline Neljäs julkaisukanava & Kohdeyleisöjen tavoittaminen & $\begin{array}{l}\text { Kattavuus } \\
\text { Universaalius } \\
\text { Innovatiivisuus }\end{array}$ \\
\hline $\begin{array}{l}\text { Sosiaalisen median } \\
\text { hyödyntäminen }\end{array}$ & $\begin{array}{l}\text { Markkinointi, brändinrakennus ja } \\
\text { Ylen tunnettuus } \\
\text { Vuorovaikutus ja median kaksi- } \\
\text { suuntaisuus } \\
\text { Sisältöjen jakelu }\end{array}$ & $\begin{array}{l}\text { Universaalius } \\
\text { Tavoittavuus } \\
\text { Kattavuus } \\
\text { Korkea laatu }\end{array}$ \\
\hline $\begin{array}{l}\text { Analytiikka ohjaavana } \\
\text { tekijänä }\end{array}$ & $\begin{array}{l}\text { Suosittujen sisältöjen tunnistaminen } \\
\text { Alustan logiikan noudattaminen }\end{array}$ & $\begin{array}{l}\text { Innovatiivisuus } \\
\text { Yhtäläinen palvelu }\end{array}$ \\
\hline $\begin{array}{l}\text { Natiivisisällöt vs. } \\
\text { oma alusta }\end{array}$ & $\begin{array}{l}\text { Uusien yleisöjen (erityisesti nuoret) } \\
\text { tavoittaminen } \\
\text { Sisältöjen saavutettavuus }\end{array}$ & $\begin{array}{l}\text { Riippumattomuus } \\
\text { Universaalius } \\
\text { Saavutettavuus } \\
\text { Tavoittavuus } \\
\text { Kansalaisoikeuksien ja } \\
\text { demokratian edistäminen }\end{array}$ \\
\hline Vaarat vs. Ylen vastuu & $\begin{array}{l}\text { Alustojen bisneslogiikan } \\
\text { tiedostaminen } \\
\text { Alustojen ehdoilla toimimisen } \\
\text { riskien tunnistaminen } \\
\text { Verkon sisältöjen toden- } \\
\text { mukaisuuden edistäminen } \\
\text { Sivistyneen keskustelun tukeminen }\end{array}$ & $\begin{array}{l}\text { Vastuullisuus } \\
\text { Riippumattomuus } \\
\text { Totuuden ja oikeudenmukaisuuden } \\
\text { edistäminen }\end{array}$ \\
\hline Epävarma tulevaisuus & $\begin{array}{l}\text { Riski alustojen katoamisesta } \\
\text { Ei mahdollisuutta kontrolloida } \\
\text { somen jakelualustojen kehitystä ja } \\
\text { alustayhtiöiden ratkaisuja }\end{array}$ & Riippumattomuus \\
\hline
\end{tabular}

Kaikkiaan tasapainottelun ajatus kietoutui aineistossa vahvasti arvoista ponnistaviin perusteluihin. Haastateltavien puheessa korostuivat erityisesti universaaliuteen liittyvät tavoitteet ja tasapainottelu, huolet Yleisradion riippumattomuudesta tulevaisuudessa sekä kansalaisyhteiskunnan ja demokratian edistäminen (ks. Taulukko 1). Koska nämä kolme arvoa yhdistyivät selkeimmin juuri alustoista käytävään keskusteluun, päädyimme jäsentämään laadullisen analyysimme tulokset niiden kautta. Raportoimme seuraavaksi analyysin tulokset kuvaamalla ensin, millä tavoin alustaistumiseen kytkeytyvä tasapainottelu näkyy 
haastatteluaineistossa. Tämän jälkeen käsittelemme aineistossa esiintyvää arvopuhetta yllä mainittujen kolmen julkisen palvelun median arvon eli universaaliuden, riippumattomuuden ja yhteiskunnan palvelemisen kautta (vrt. Lowe 2010, 26).

\section{Alustaistuminen tasapainotteluna}

Ensimmäisessä tutkimuskysymyksessä kysymme, miten Yleisradiossa kuvataan ja perustellaan suhdetta sosiaalisen median alustoihin. Analyysimme osoittaa, että Yleisradion suhde sosiaalisen median alustoihin näyttäytyy haastateltavien puheessa tasapainottelun ja jatkuvan arvoihin kytkeytyvän pohdinnan kautta. Yleisradion suhdetta sosiaalisen median alustoihin pohdittiin erityisesti alustojen kaksijakoisen roolin kautta (oma julkaisukanava vs. alustojen hyödyntäminen sisältöjen markkinoinnissa), analytiikan roolin kautta sekä alustoihin liittyvien vaarojen, vastuiden ja tulevaisuudenkuvien kautta (ks. Taulukko 1). Tasapainottelu ei siis kuvaa terminä vain julkisen palvelun mediayhtiössä tehtävää käytännön työtä, vaan heijastelee laajemmin sosiaalisen median alustoilla toimimiseen liittyvää jatkuvaa tarvetta tasapainotella mediayhtiön omien toimintatapojen ja niitä ohjaavien arvojen sekä alustojen logiikoiden ja niiden takana piilevien arvojen välillä. Kuvaamme tässä osiossa tätä tasapainottelua haastateltaviemme puheessa ilmenneiden tavoitteiden ja toimintatapojen kautta. Seuraava osio liittää tämän puheen osaksi pohdintaa julkisen palvelun median arvoista.

Tasapainottelun tematiikka ilmeni haastateltavien puheessa pohdintana sosiaalisen median alustojen rooleista julkaisukanavina. Käytännön tasolla haastateltavat pohtivat natiivisisältöjen tuottamista sosiaalisen median alustoille sekä yleisöjen aktiivista ohjaamista Yleisradion omille alustoille. Niin kutsutut natiivisisällöt on suunniteltu kulutettavaksi sosiaalisen median alustoilla, eikä niiden kuluttaminen siten vaadi siirtymistä Yleisradion omille verkkoalustoille. Tasapainottelu tiivistyy siis siihen, suhtaudutaanko sosiaaliseen mediaan omana julkaisukanavanaan vai markkinointivälineenä, jonka kautta Yleisradio voi vahvistaa brändiään ja mainostaa sisältöjään.

Haastatteluiden perusteella näkemykset ja käytännöt vaihtelevat Ylen sisällä paljon. Osa haastateltavista kertoi pohtivansa päivittäisessä työssään usein sitä, missä heidän osastonsa tuottamia sisältöjä julkaistaan ja voiko sisältöjä ylipäätään tehdä vain sosiaalista mediaa varten. Osa haastateltavista oli sitä mieltä, että yleisöt pitäisi pyrkiä tavoittamaan siellä, missä he jo valmiiksi ovat ja ohjata heidät sitten kuluttamaan Ylen sisältöjä yhtiön omille alustoille. Tällaisessa ajattelutavassa sosiaalinen media näyttäytyy lähinnä markkinointialustana, jonka avulla Ylen sisältöjä pyritään tekemään tunnetuiksi. Moni haastateltava totesi myös, että Ylen pitäisi tällaisessa mallissa pystyä tarjoamaan yleisölle omalla alustallaan kiinnostavampaa ja merkityksellisempää sisältöä kuin mitä sosiaalisen median alustat itsessään tarjoavat.

Yhtäältä mä ajattelen silleen, että journalismi tehdään muualla kuin somessa ja sitten sitä journalismia myydään, sitä niin ku hierotaan kasvoille tai tehdään kiinnostavaksi siellä somessa, jotta ihmiset huomais ja lukis ja tulis pois sieltä omille alustoille. Mutta sitten taas toisaalta me saatetaan aiheuttaa sitä tällaisella toiminnalla, että se some tyhmenee koko ajan (...) [H1O] 
Monet haastateltavat näkivät yleisöjen ohjaamisen sosiaalisesta mediasta omille verkkoalustoille varsin työläänä etenkin, jos tavoitellut kohdeyleisöt ovat tottuneet käyttämään sosiaalista mediaa eivätkä Ylen alustat ole heille tuttuja. Osa haastateltavista oli kuitenkin toiveikkaita sen suhteen, että jos Yle tehdään yleisöille tarpeeksi tutuksi sosiaalisessa mediassa, he innostuvat tulemaan kiinnostavien sisältöjen perässä muillekin alustoille.

Se on tosi vaikeeta saada ihmisille jotenkin niiden rajattuihin päiviin tavallaan niitä aikaikkunoita, että ne jaksais tulla jollekin toisellekin alustalle ku sinne missä ne pyörii. Että jos ihmisillä on joku muutama äppi vaikka puhelimessa, mitä ne käyttää ja se, että jos me pystytään saamaan meidän sisällöt esiin sitten siellä äpissä, missä ne käyttää sitä ja sitten kun se tulee niille tutuksi se sisältö, niin sitten ne ehkä kiinnostuu menemään sen perässä jonnekin muuallekin. [H6]

Sosiaalisen median alustojen vahvaa roolia sekä median alustaistumista ja dataistumista korostaa tapa, jolla haastateltavat puhuvat Yleisradion käytännöistä seurata tarkasti sosiaalisen median alustoilta saatavaa dataa, kuten sisältöjen käyttäjämääriä, niiden parissa vietettyä aikaa ja sitä, miten käyttäjät ohjautuvat sosiaalisesta mediasta Ylen omille verkkoalustoille. Osa haastateltavista jopa ilmaisi datan ja siitä tehtävän analytiikan edustavan heille yleisöä. Data nähtiin ikään kuin sosiaalisesta mediasta saatavana välittömänä palautteena, jonka avulla voidaan arvioida, millaiset sisällöt ja formaatit toimivat eri alustoilla tai millaiset aiheet yleisöä kiinnostavat, ja jonka avulla voidaan siten kehittää sisällöntuotantoa haluttuun suuntaan. Yleisön käyttäytyminen alustoilla ja siitä saatava data ohjaa siis ainakin osittain sosiaalisen median alustoihin liittyvää työtä ja valintoja Yleisradiossa.

Sanoisin, että jotenkin sen sisällön pitää aina olla silleen datalähtöistä, että mitään ei ole järkevää tehdä, jos se ei tavoita. Ja sitten datasta totta kai voidaan jälkikäteen niin ku päätellä, että mikä toimi ja mikä ei ja sen pitää pystyä ohjaamaan sitten sitä jatkotekemistä. [H6]

Analytiikan lisäksi Yleisradion sosiaalisen median käyttöä ohjaa myös muu alustoilla menestyvä sisältö. Osa haastateltavista kertoi esimerkiksi seuraavansa aktiivisesti eri alustoilla olevia listauksia niiden suosituimmista sisällöistä ja ottavansa Ylen sisällöntuotantoon mallia alustoilla menestyvistä aiheista ja sisältöformaateista. Alustoilla menestymisen koettiin siis vaativan sopeutumista sosiaalisen median logiikkaan, jossa muun muassa erilaiset algoritmit ja automaattinen personointi vaikuttavat sisältöjen leviämiseen (esim. Van Dijck, Poell ja de Waal 2018; Just ja Latzer 2017). Arvojen näkökulmasta on kuitenkin kiinnostavaa, että kaikkia näitä dataan ja teknologiseen logiikkaan kytkeytyviä arkisiakin haasteita pohditaan aineistossamme julkisen median tehtävän ja arvojen kautta.

Tasapainottelun logiikkaa kuvaa myös se, että osa haastateltavista ei pitänyt mielekkäänä Ylen omien verkkoalustojen ja sosiaalisen median alustojen vastakkainasettelua. Sen sijaan alustat nähtiin Ylen toiminnan kannalta yhtä tärkeinä ja toisiaan täydentävinä. Eräs haastateltava esitti toiveen, että Ylen omia alustoja ja sosiaalista mediaa ei aina lähtökohtaisesti asetettaisi vastakkain. Hän kuitenkin myös totesi, että "tää on semmoinen asia, mistä ollaan ehkä montaa eri mieltä yhtiön sisällä" [H1]. Tämä lainaus kuvaakin erinomaisesti haastatteluaineistossamme näkyvää tasapainottelun ajatusta: on selvää, että Yleis- 
radion sisällä käydään jatkuvaa keskustelua yhtiön alustasuhteesta ja siitä neuvotellaan paitsi someverkoston tapaamisissa, myös strategisissa linjauksissa ja käytännön toimitustyön arjessa. Haastateltavien pohdinta sosiaalisen median alustojen asemasta julkaisu- tai markkinointikanavina liittyy "uuden universaaliuden" toteuttamiseen ja saavutettavuuden ja tavoittavuuden kysymyksiin. Pureudumme tähän universaaliuden arvoon kytkeytyvään puheeseen tarkemmin seuraavassa osiossa.

\section{Alustaistuminen ja arvopuhe}

Universaalius. Universaaliuden arvo näyttäytyi erityisesti sisältöjen saavutettavuuden ja tavoittavuuden kautta haastateltavien kuvatessa Yleisradion suhdetta sosiaaliseen mediaan. Universaalin palvelun kannalta sosiaalisen median hyödyntämisen julkaisukanavana nähtiin auttavan Yleisradion sisältöjen tavoittavuutta yleisöille, jotka eivät ole tottuneet käyttämään Ylen omia palveluita televisiossa, radiossa tai verkossa. Samalla alustojen toimintalogiikassa nähtiin kuitenkin ongelmia, jotka haastavat julkisen palvelun tehtävien toteutumista.

Läsnäoloa sosiaalisessa mediassa pidettiin Yleisradiossa lähes välttämättömänä erityisesti tavoiteltaessa nuoria yleisöjä, joille ei ole välttämättä muodostunut henkilökohtaista suhdetta Yleisradioon. Kuten Schulz ja kumppanit (2019, 15-19) ovat todenneet, monet yleisradioyhtiöt ovat epäonnistuneet nuorten tavoittamisessa, kun nuorten median kulutus keskittyy yhä enemmän sosiaaliseen mediaan (esim. Reunanen 2020). Tässä mielessä Ylen sosiaalisen median toiminta kytkeytyy suoraan tiettyjen yleisöryhmien tavoittamiseen, mikä kuvaa niin sanotun "uuden universaaliuden" eetosta julkisen palvelun median toiminnassa (vrt. van den Bulck ja Moe 2018). Osa haastateltavista ajattelikin, että yleisöä ei pitäisi pakottaa siirtymään pois sosiaalisen median alustoilta, jotta he voisivat kuluttaa Yleisradion sisältöjä. Nuorten tavoittaminen on olennaista myös yleisradioyhtiöiden tulevaisuuden suhteen, sillä ne tarvitsevat laajan yleisön oman legitimiteettinsä perustelun kannalta (Schulz, Levy ja Nielsen 2019, 30).

Oma mielipiteeni on, että kyllä mä olen hieman skeptinen siitä, että saadaanko sitä nuorta sukupolvea ja sitä Yle-suhdetta heihin, että tota. Tai voi olla, että niillä joku Yle-suhde on, mutta ei niitä kiinnosta se, että kattooko ne Areenasta vai Youtubesta. Ne haluaa katsoa sen sieltä, missä se on helpointa ja todennäköisesti niille se helpoin paikka on Youtube, kun ne on siellä muutenkin. -- Että kyllä näinä päivinä, kun yleisön ja käyttäjän pitäisi olla kaiken keskiössä, niin miksi me tehdään se heille vaikeaksi. [H8]

Yleisradiossa on myös läsnä vahva diskurssi siitä, että yhtiön on oltava mukana kaikkien suomalaisten arjessa. Lowen (2010, 26) mukaan julkisen palvelun median jakelukanavien on tyydytettävä yhteiskunnan tarpeita, minkä voidaankin nähdä perustelevan sosiaalisen median hyödyntämistä, sillä sen kautta on mahdollista vastata tehokkaasti erityisesti nuorten yleisöjen tapoihin viestiä ja kuluttaa mediaa. Tässä tarkoituksessa sosiaalista mediaa hyödyntävät voimakkaimmin Yleisradion niin kutsutut nuorisomediat Yle X ja Yle Kioski. Molemmille osastoille sosiaalisen median alustat toimivat niiden tuottamien videosisältöjen 
pääjulkaisukanavina. Vaikka osastojen sisällöt ovat saatavilla myös Yle Areenasta, sosiaalisen median nähtiin vastaavan tehokkaammin nuorten kohdeyleisöjen mediankäyttötottumuksiin.

Eihän niitä kukaan sieltä [Yle Areenasta] katso. Sieltä niitä katsoo joku 100 ihmistä tai 300 ja nekin on varmaan Ylen sisäisiä, koska ei kukaan meidän kohderyhmästä tule tietoisesti Areenaan etsimään meidän sisältöjä, kun niiden [nuorten] kulutusrajapinnat ja se mediankäyttö on niin eri paikoissa. $\left[\mathrm{H}_{5}\right]$

Toisaalta universaalin palvelun kysymys liittyy myös laajasti alustoihin kytkeytyvään epävarmaan tulevaisuuteen, kuten siihen ovatko alustat käytössä vielä vuosien kuluttua ja millä ehdoilla. Universaalin palvelun toteutumisen kannalta haastateltavat pitivät kuitenkin tärkeänä, että kaikki Yleisradion sisällöt ovat saatavilla myös Ylen omilla verkkoalustoilla. Siten ne ovat saavutettavissa paitsi pidemmällä aikajaksolla, myös sellaisille yleisöille, jotka eivät käytä sosiaalista mediaa. "Uuteen universaaliuteen" uskominen ei siis haastateltaviemme keskuudessa näyttäytynyt yksioikoisena, vaan he pohtivat sisältöjen jakelua sekä niiden tavoittavuuden että saavutettavuuden kannalta. Tutkimuksemme sosiaaliseen mediaan keskittyvä konteksti toki korostaa erityisesti tavoittavuuteen liittyviä näkökulmia, kun sisältöjä jaetaan palveluissa alustojen algoritmien ehdoilla.

Riippumattomuus. Pohdinnat alustojen luomasta epävarmasta tulevaisuudesta kytkeytyvät arvopuheen näkökulmasta erityisesti julkisen palvelun median riippumattomuuteen (Lowe 2010, 26; Yle 2017). Riippumattomuuteen liittyvä keskustelu kiertyy toisaalta sisältöjen, toisaalta alustojen taloudellisten omistussuhteiden ympärille.

Sosiaalisen median alustojen nähtiin osin haastavan toimituksellisen riippumattomuuden erityisesti mediasisältöjen levittämisen näkökulmasta. Useat haastateltavat mainitsivat Yleisradion olevan sosiaalisessa mediassa aina alustojen algoritmien armoilla. Alustojen automaattinen personointi, algoritmit, käyttäjien toiminta ja sisältöjen saama huomio vaikuttavat merkittävästi sisältöjen leviämiseen ja näkyvyyteen (Van Dijck ja Poell 2013; Van Dijck, Poell ja de Waal 2018), mitä voidaan pitää ongelmallisena niin sisältöjen jakelun kuin toiminnan läpinäkyvyydenkin kannalta. Sosiaalisessa mediassa Yle joutuu toimimaan alustojen ehdoilla eikä pysty tekemään valintoja sisältöjen arvottamisen suhteen, kun taas omilla verkkoalustoillaan Yle voi nostaa tiettyjä sisältöjä näkyvimmille paikoille ja siten osoittaa niiden olevan esimerkiksi uutisarvoltaan merkittäviä.

No meille tietysti niin kuin julkisen palvelun yleisradioyhtiönä on ne omat alustat myös tosi tärkeitä. Eli meidän pitää niin kuin tavalla tai toisella aina pystyä varmistamaan se, että meillä on semmoinen kotipesä, jonka esimerkiksi algoritmeistä me voidaan olla läpinäkyviä. Ja voidaan niin kuin avoimesti ihmisille kertoa, että meidän arvot on nämä ja nämä ja jos tulet meidän palveluun, niin meidän algoritmit toimii tällä tavalla. [H4]

Riippumattomuutta käsittelevään arvopuheeseen kytkeytyy myös alustojen omistukseen liittyviä näkökulmia. Yleisradion omien alustojen eduiksi haastateltavat mainitsivat mahdollisuudet vaikuttaa alustojen kehitystyöhön sekä oman, sosiaalisen median alustoista riippumattoman datan keräämiseen. Eräs haastateltava korosti, miten sosiaalisen median 
alustojen kohdalla täytyy aina pitää mielessä niiden omistajayhtiöiden tavoitteet. Usein sosiaalisen median sovellukseen päivityksen myötä tulleet uudet ominaisuudet voivat vaikuttaa hyödyllisiltä, mutta toisaalta kehittäjien tavoitteena on niiden avulla lisätä ihmisten sovelluksessa viettämää aikaa. Tämä puolestaan vähentää Ylen näkyvyyttä ja Ylen omien palveluiden parissa vietettyä aikaa. Haastateltavat pohtivat myös Yleisradion riippuvuutta sosiaalisen median datasta, jonka merkitystä mediatyössä kuvasimme aiemmin: numerot ovat vahva mittari sisältöjen suosiosta, toisaalta niiden saatavuus tulevaisuudessa näyttäytyy epävarmana:

(...) niin se on tässä niin ku ehkä pelottava kehityskulma ja just se että jossain vaiheessa sekin, että me nyt tällä hetkellä saadaan ilmaseks näitä datoja, et miten paljon me saadaan klikkejä meidän omille sivustoille, niin jossain vaiheessa tää varmaan alkaa maksaa. [H1]

Tasapainottelu sosiaalisen median hyödyntämisessä liittyy myös Yleisradion julkiseen rahoitukseen ja sen mukanaan tuomiin edellytyksiin. Osa haastateltavista näki ristiriidan siinä, että kansalaisilta kerätyillä verorahoilla operoiva Yleisradio toimii pitkälti yhdysvaltalaisten yritysten omistuksessa olevilla alustoilla. Julkaistessaan omia sisältöjään sosiaalisessa mediassa Yleisradio tavallaan antaa sisältöjä ilmaiseksi näille yrityksille ja edistää sitä, että inmiset viettävät mahdollisimman paljon aikaa niiden omistamilla alustoilla, siten tukien niiden liiketoimintaa. Myös Moe $(2013,120)$ sekä Nikunen ja Hokka $(2020,3)$ ovat huomauttaneet, että levittäessään sisältöjään sosiaalisessa mediassa yleisradioyhtiöt edistävät kaupallisten alustayritysten kasvua sekä vahvistavat niiden valtaa yhteiskunnallisen keskustelun fasilitoijina (ks. myös Helberger 2020).

Yhteiskunnan palveleminen. Vaikka Yleisradion toiminnan riippumattomuuteen ja alustayhtiöiden ansaintamalleihin liittyvä ristiriita oli vahvasti läsnä haastateltavien puheessa, oli taloudellisiin resursseihin liittyvä näkökulma myös yksi peruste Yleisradion läsnäololle sosiaalisessa mediassa. Osa haastateltavista näki Yleisradiolla olevan vastuun olla läsnä ja julkaista sisältöjä sosiaalisessa mediassa, sillä verorahoitteisuutensa puolesta Ylellä on suomalaista kaupallista mediaa laajemmat mahdollisuudet tehdä erilaisia sisältökokeiluja alustoilla.

Musta se on niin ku Ylen tehtäväkin siis versus sitten kaupalliset mediat se, että niin ku tavallaan testata näitä juttuja, koska meillä on ne resurssit vähän erilaiset. [H6]

Läsnäolon vastuun painottaminen kytkeytyy julkisen palvelun median arvoon, jonka mukaan yleisradioyhtiön tehtävä on palvella yhteiskuntaa ja vahvistaa yhteiskunnallista keskustelua (Lowe 2010, 26). Yhteiskunnallinen arvopuhe näkyi erityisesti siinä, miten haastateltavat kuvasivat Yleisradion velvollisuutta olla luotettava ja läsnäoleva mediatoimija kansalaisten parissa. Läsnäoloa sosiaalisessa mediassa perusteltiinkin Yleisradion vastuulla tuoda alustoille luotettavaa ja laadukasta sisältöä. Eri sosiaalisen median alustoilla nähtiin olevan esimerkiksi faktapohjaisen, journalistisin perustein tuotetun tiedon mentävä aukko, jonka Yleisradio voisi täyttää. 
[Youtubessa] on niin ku vaikka tubettajia, jotka avaa arkeaan tai puhuu jostain tämmösistä niin ku ihmissuhteesta ja tällasista asioista, että sen vähän journalistisemman klangin sinne voi kyllä Yle tuoda, kun se tuo sen vaan ottaen huomioon sen tekemistavan. [H5]

Osa haastateltavista myös pohti aktiivisesti, millä tavoin he voivat oman toimintansa kautta vaikuttaa alustojen järjestämään julkisuuteen, jonka tiedetään tukevan esimerkiksi polarisoitumista, populistista politiikkaa tai valeuutisten leviämistä (esim. Laaksonen 2020). Eräs haastateltava aprikoi, olisiko mediayhtiön mahdollista toimia korjaavana voimana, mutta koki samalla voimattomuutta algoritmien edessä:

Niin, me ollaan mietitty tosi paljon, että meidän yksi tehtävä somessa on ehkä journalistisesti just se, että me tuotais tasapainoa siihen arvomaailmaan, joka saattaa vääristyä. Mutta se ei ole kovin helppoa, kun me ei voida muokata niitä algoritmejä. [H1O]

Haastateltavat huomioivat myös sosiaalisen median merkityksen kasvun uutisten kuluttamisen suhteen. Vaikka Suomessa ollaan edelleen varsin uskollisia perinteisille medioille ja uutisia käydään lukemassa paljon niiden omilta verkkosivuilta (Reunanen 2020, 53), oli osalla haastateltavista se käsitys, että erityisesti nuoret etsivät uutissisältöjä entistä enemmän ensisijaisesti sosiaalisen median alustoilta. Haastateltavien näkemysten mukaan kuluttajien voi kuitenkin olla vaikeaa tunnistaa, mikä sosiaalisessa mediassa leviävä tieto on luotettavaa, sillä valeuutiset ja disinformaatio saavat alustoilla herkästi paljon näkyvyyttä. Lowen (2010, 25) mukaan yhteiskuntaa palvellakseen julkisen palvelun median onkin edistettävä muun muassa totuutta.

Jos fake news on niin ku valtavan iso ongelma jo nyt [sosiaalisessa mediassa], varsinkin englanninkielisessä maailmassa, niin meidän pitää olla läsnä niillä omilla journalistisilla kriteereillä ja pyrkiä välittämään niitä rehellisiä, totuudellisia viestejä. [H1O]

Yleisradion arvoihin pohjautuva, yhteiskunnallinen rooli näyttäytyy lisäksi yleisöjen osallistumisen ja keskustelun edistäjänä. Haastateltavat näkevät vuorovaikutteisuuden yhtenä sosiaalisen median keskeisenä ominaisuutena, mutta toisaalta myös sellaisena toiminnallisuutena, joka istuu helposti Yleisradion arvoihin yhteiskunnallisena toimijana. He kuitenkin mainitsevat keskustelun tukemiseen liittyviä hankaluuksia, kuten omien alustojen jäykkyyden sekä moderoinnin suuren tarpeen. Riippumattomuuden ajatus on kuitenkin läsnä myös keskustelujen edistämisessä, sillä keskustelun ohjaaminen koetaan helpommaksi omalla alustalla.

Siis että me tehdään sisältöjä, jotka me annetaan joko ihan omissa niin ku vaikka Areenassa tai telkkarissa nähty suorana jotain. Niin sittenhän se on yleisön omaisuutta sen jälkeen. He ovat kokeneet, nähneet jotain, sitten he keskustelevat siitä ihan ilman, että me tehdään yhtään mitään. Ja se on tosi tosi tärkeetä. Ja sit toisaalta meillä on sitten omat kanavat, joissa me jollain tapaa pystytään ehkä hallitsemaan niitä keskusteluja. [H2] 
Aineistossa esiintyvät yhteiskunnan palvelemiseen liittyvät perustelut kietoutuvat moniin eri julkisen palvelun arvoihin. Sisältökokeilut eri alustoilla voidaan nähdä innovatiivisuutena (EBU 2012), faktapohjaisten ja luotettavien sisältöjen tuottaminen sosiaalisen median alustoille kansalaisten tiedontarpeiden tyydyttämisenä nimenomaan laadukkaalla sisällöllä, sekä keskustelujen fasilitoiminen sosiaalisessa mediassa ja omilla alustoilla kansalaisten osallistumismahdollisuuksien ja demokratian tukemisena (Lowe 2010, 26). Huomionarvoista on myös, että haastateltavien puhe heijastelee Yleisradion virallista strategiaa, jonka mukaan Ylen missiona on esimerkiksi vahvistaa suomalaista yhteiskuntaa ja kulttuuria (Yle 2017; Yle 2020). Haastateltavat siis sekä toistavat puheessaan organisaatiossa vallitsevia arvoja että osallistuvat niiden määrittelemiseen (Meyer 1995, 218).

\section{Johtopäätökset ja diskussio}

Tämän tutkimuksen tarkoituksena oli yhtäältä selvittää, miten Yleisradiossa kuvataan ja perustellaan suhdetta sosiaalisen median alustoihin ja toisaalta, minkälaiseen arvopuheeseen suhteen kuvaaminen kytkeytyy. Analyysimme osoittaa, että Yleisradion suhde sosiaalisen median alustoihin sekä siihen liittyvä arvopuhe kiertyvät tasapainottelun tematiikan ympärille. Terminä tasapainottelu heijastelee sekä käytännön työssä että puheen tasolla Yleisradiossa ilmenevää jatkuvaa tarvetta neuvotella sosiaalisen median alustoilla toimimiseen liittyvistä toimintatavoista ja niihin kytkeytyvistä arvoista. Tasapainottelu kytkeytyi aineistossa vahvasti kysymyksiin Yleisradion yhteiskunnallisesta roolista ja vastuusta julkisen palvelun mediana: Ylen vastuuna nähtiin läsnäolo sosiaalisessa mediassa, vaikka samanaikaisesti haastateltavat kokivat selvää ristiriitaa sosiaalisen median alustoihin liittyvien piirteiden ja Yleisradion arvopohjan välillä.

Vaikka median alustasuhteeseen liittyvästä tasapainottelusta on keskusteltu aiemmin (esim. Helberger 2020), tämä artikkeli tuottaa lisää ymmärrystä siitä, minkälaisiin alustojen ominaisuuksiin ja dataan liittyviin teemoihin tasapainottelu kytkeytyy ja kontribuoi tutkimukseen käsitteellistämällä tasapainottelun organisaation ja median arvoihin liittyväksi diskursiiviseksi toiminnaksi. Tasapainottelu on esimerkki arvokäytänteistä (Gehman, Treviño ja Garud 2013, 86-87): sosiaalisen median käyttöön liittyviä valintoja tehdään eri puolilla Yleisradiota, ja näiden käytänteiden kautta arvovalinnat tulevat näkyviksi, arvoja tuotetaan ja ne performoidaan.

Julkisen palvelun median keskeiseksi arvoksi nostettu universaaliuden arvo (Debrett $2010,187)$ näyttäytyi erityisesti sisältöjen saavutettavuuden ja tavoittavuuden kautta. Sosiaalisen median hyödyntäminen julkaisukanavana nähtiin tärkeänä, jotta Yleisradion sisällöt tavoittaisivat sellaiset yleisöt, jotka eivät ole tottuneet käyttämään Ylen omia palveluita erityisesti nuoret yleisöt. Toisaalta haastateltavat pitivät tärkeänä, että kaikki Yleisradion sisällöt ovat saatavilla lisäksi sen omilla verkkoalustoilla, jolloin ne ovat vapaasti kaikkien saavutettavissa. Kuten Nikunen ja Hokka (2020, 2) sekä Hokka (2019) kirjoittavat, universaalia palvelua on perinteisesti jäsennetty tutkimuskirjallisuudessa sekä sisältöjen saavutettavuuden että niiden monimuotoisuuden kannalta. Haastateltaviemme puheessa universaalius kuitenkin korostui alustasuhteen puristuksessa nimenomaan tavoittavuutena monimuotoisuuden sijaan. Tämä lienee luonnollista sikäli, että keskustelu sosiaalisen median 
algoritmeista ajaa mediatoimijat helposti miettimään yleisöjen tavoittamista ilman alustojen sekaantumista. Kiinnostavaa on, että arvopuheen näkökulmasta alustaistuminen vaikuttaisi muokkaavan samalla myös sitä, miten perinteisiä arvoja uusinnetaan Yleisradion arjessa.

Aineistossa esiintyi myös arvopohjaista puhetta Yleisradion riippumattomuudesta sosiaalisen median alustoilla toimimisesta. Haastateltavien mukaan yksi merkittävä ongelma on se, että sosiaalisen median alustoilla toimiessaan Yleisradio on aina alustojen algoritmien armoilla (esim. Van Dijck, Poell ja de Waal 2018) eikä pysty siten vaikuttamaan sisältöjen näkyvyyteen tai arvottamaan niiden tärkeyttä. Molemmilla seikoilla voi olla heikentävä vaikutus Ylen tuottamien sisältöjen saavutettavuuteen, minkä haastateltavat myös tiedostivat. Alustojen ehdoilla toimiminen näkyy myös tavassa, jolla haastateltavat luonnehtivat sosiaalisesta mediasta saatavan datan sekä alustoilla menestyvien sisältöjen merkitystä työssään. Tarkka datan seuraaminen ja dataan osittain pohjautuva sisällöntuotanto kuvaavatkin sitä, miten Ylen on sopeuduttava alustojen toimintamekanismeihin maksimoidakseen sisältöjensä näkyvyyden.

Julkaistessaan tekemiään sisältöjä sosiaalisessa mediassa Ylen voidaan nähdä antavan sisältöjä ilmaiseksi yksityisille yrityksille ja edistävän sitä, että inmiset viettävät mahdollisimman paljon aikaa näillä enimmäkseen yhdysvaltalaisomisteisilla alustoilla. Aiemmassa tutkimuksessa onkin todettu, että yleisradioyhtiöt voidaan nähdä epäkaupallisina toimijoina, jotka astuvat globaalien kaupallisten yhtiöiden hallitsemalle alueelle hyödyntäessään sosiaalisen median alustoja (Nikunen ja Hokka 2020, 3; Moe 2013, 115). Tämä herättää kysymyksiä riippumattomuudesta sekä tavasta käyttää julkisia verorahoja. Lisäksi riippumattomuus kytkeytyy kysymyksiin median dataistumisesta: kun Yleisradion toiminnan arviointi pohjautuu osittain alustoilta saatavaan dataan, haastateltavat esittivät huolensa siitä, millä varmuudella nämä datat ovat myös jatkossa saatavilla.

Toisaalta julkisen palvelun median yhteiskunnan palvelemista korostavan arvon (Lowe 2010, 26) nähtiin perustelevan Yleisradion vahvaa läsnäoloa sosiaalisessa mediassa. Median kulutuksen keskittyessä entistä enemmän sosiaaliseen mediaan Ylen vastuuna nähtiin luotettavan ja riippumattoman journalistisen sisällön tuominen alustoille. Parhaimmillaan julkisen palvelun median yhteiskunnallinen arvoihin pohjautuva rooli voi haastateltavien mukaan toteutua julkista keskustelua faktoittavan ja tasapainottavan läsnäolon kautta. Arvojen ja arvopuheen performatiivisuus (esim. Gehman, Treviño ja Garud 2013, 104-105) korostuu erityisesti Yleisradion yhteiskunnallisesta vastuusta puhuttaessa. Median perinteikäs julkisen palvelun arvo, joka on myös kirjattu Yleisradion strategiaan, näyttäytyy aineistossa haastateltavien toimintaa ja päätöksentekoa ohjaavana arvona, jota pyritään myös uusintamaan Yleisradion sosiaalisen median toiminnan kautta.

Tulosten pohjalta voidaan todeta, että Ylen toiminta sosiaalisen median alustoilla pohjautuu sen oman legitimiteetin varmistamisen lisäksi eettisyyteen ja vahvaan julkisen palvelun eetokseen. Eetos näkyy erityisesti Yleisradion sosiaalisen median toimijoiden arvopuheessa. Tämä erottaa Yleisradion jossain määrin kaupallisesta mediasta. Esimerkiksi sanomalehdille sosiaalisen median alustat ovat merkittävä keino tavoittaa yleisöä ja siten saada uusia maksavia tilaajia (Lehtisaari ym. 2018, 1031), eikä niiden välttämättä tarvitse pohtia samanlaisia vastuukysymyksiä esimerkiksi universaalin palvelun tarjoamiseen liittyen kuin julkisen palvelun median. 
Aiemmissa tutkimuksissa on todettu, että selviytyäkseen nykyaikaisen mediamaiseman asettamista haasteista, yleisradioyhtiöiden on sopeutettava toimintojaan uuteen ympäristöön (Larsen 2014, 73-74). Toisinaan aiempi tutkimus julkisen palvelun mediayhtiöiden alustaistumisesta luo kuvaa maailmasta, jossa yleisradioyhtiöt kulkevat alustayhtiöiden talutusnuorassa (Nikunen ja Hokka 2020; Hokka 2017; Rashidian ym. 2019). Tämän tutkimuksen tulokset kuitenkin osoittavat, että tilanne ei ole aivan niin mustavalkoinen. Yleisradiossa tiedostettiin alustaistumisen julkiselle palvelulle asettamat haasteet sekä käytiin aktiivista dialogia ja neuvottelua sisältöjen tuotanto- ja julkaisuprosessia ohjaavista arvoista. Alustoihin sopeutumisen ei tarvitse tarkoittaa arvopohjasta luopumista ja alustayhtiöiden rakentaman infrastruktuurin kritiikitöntä omaksumista. Alustayhtiöiden teknologiset toiminnallisuudet myös monilla tavoin tukevat niitä arvopohjaisia periaatteita, joille julkisen palvelun media rakentuu: ne mahdollistavat laajempien yleisöjen tavoittamisen ja yhteiskunnallisen keskustelun tukemisen. Erityisesti ajatus julkisen palvelun mediasta universaalisti läsnä olevana, yhteiskunnallista julkisuutta tasapainottavana toimijana on kiinnostava arvopohjainen roolitus, jonka alustaistunut mediamaisema mahdollistaa.

Sosiaalisen median alustat eivät siis vain yksipuolisesti muuta media-alan prosesseja, vaan osin myös olemassaolollaan tukevat arvopohjaista keskustelua, jopa ajavat julkisen palvelun mediaa pohtimaan omia arvojaan. Erityisesti universaaliuden toteuttamista olisi tärkeää tarkastella yleisradioyhtiöissä tarkoin, jotta sosiaalisen median alustojen hyödyntäminen jakelun ja markkinoinnin kanavina ei palvele vain yksittäisten käyttäjien tarpeita vaan luo myös aidosti tilaa yhteiselle julkiselle keskustelulle. Aineistossamme heijastuvat Yleisradion sisäiset pohdinnat ovat relevantteja julkisen palvelun arvoille laajemminkin, sillä ne voivat osaltaan ohjata sitä, miten julkisen palvelun periaatteita yleisradioyhtiöissä tulevaisuudessa toteutetaan.

Tulostemme yleistettävyyttä rajoittaa niiden kohdistuminen vain yhteen yleisradioyhtiöön ja toisaalta haastateltavien pieni lukumäärä. Haastateltujen otos kuitenkin kattaa paitsi journalisteja, myös muissa rooleissa työskenteleviä media-alan ammattilaisia. Siinä mielessä se tarjoaa laajan näkymän niihin toimijoihin, jotka aktiivisimmin työskentelevät sosiaalisen median alustojen parissa Yleisradiossa. Jatkossa olisi kuitenkin hyödyllistä tutkia tarkemmin erityisesti journalistisia käytänteitä julkisen palvelun mediayhtiöissä alustaistumisen osalta ja verrata niitä organisaatiossa vallitseviin arvoihin. Tämä mahdollistaisi entistä yksityiskohtaisemman kuvan luomisen siitä, miten esimerkiksi sosiaalisen media toimintalogiikka muuttaa tuotantoprosesseja mediaorganisaatioiden sisällä. Lisäksi mielenkiintoista olisi myös tarkastella mediasisältöjä tuottavien työntekijöiden sekä mediaorganisaatioiden johdon käsityksiä ja niiden yhteneväisyyksiä ja eroavaisuuksia alustasuhteeseen liittyen (vrt. Donders 2019).

\section{Kiitokset}

Tutkimustamme on rahoittanut Media-alan tutkimussäätiö. Kiitämme myös haastateltaviamme ja Yleisradiota tutkimusyhteistyöstä. 


\section{Kirjallisuus}

Andersson Schwarz, Jonas. 2017. "Platform Logic: An Interdisciplinary Approach to the Platform-Based Economy." Policy and Internet 9 (4): 374-94. https://doi.org/10.1002/poi3.159.

Bansal, Pratima. 2003. "From issues to actions: The importance of individual concerns and organizational values in responding to natural environmental issues." Organization Science 14 (5): 510-527. https://doi.org/10.1287/orsc.14.5.510.16765.

Bolin, Göran. 2011. Value and the Media: Cultural Production and Consumption in Digital Markets. Farnham, UK: Ashgate.

Born, Georgina. 2004. Uncertain vision: Birt, dyke and the reinvention of the BBC. Lontoo: Secker \& Warburg.

Born, Georgina ja Tony Prosser. 2001. "Culture and Consumerism: Citizenship, Public Service Broadcasting and the BBC's Fair Trading Obligations." Modern Law Review 64 (5): 657-687. https://doi.org/10.1111/1468-2230.00345.

Bourne, Humphrey ja Mark Jenkins. 2013. “Organizational Values: A Dynamic Perspective.” Organization Studies 34 (4): 495-514. https://doi.org/10.1177/0170840612467155.

Caplan, Robyn ja Danah Boyd. 2018. "Isomorphism through Algorithms: Institutional Dependencies in the Case of Facebook." Big Data Q Society 5 (1): 1-12. https://doi.org/10.1177/2053951718757253.

Cherubini, Federica ja Rasmus Kleis Nielsen. 2016. Editorial analytics: How news media are developing and using audience data and metrics. Oxford University: Reuters Institute for the Study of Journalism.

Christensen, Lars Thøger, Mette Morsing ja Ole Thyssen. 2020. "Talk-Action Dynamics: Modalities of Aspirational Talk." Organization Studies, January 2020. https://doi.org/10.1177/0170840619896267.

Debrett, Mary. 2010. Reinventing Public Service Television for the Digital Future. Bristol: Intellect.

Deuze, Mark. 2007. Media work. Cambridge: Polity Press.

Donders, Karen. 2019. "Public Service Media beyond the Digital Hype: Distribution Strategies in a Platform Era." Media, Culture and Society 41 (7): 1011-28. https://doi.org/10.1177/0163443719857616.

European Broadcasting Union (EBU). 2012. Empowering Society: A Declaration on the Core Values of Public Service Media. Luettu 27.3.2020. http://www3.ebu.ch/cms/en/policies/initiatives/psm-values.

Enli, Gunn Sara. 2008. "Redefining public service broadcasting: Multi-platform participation." Convergence 14 (1): 105-120. https://doi.org/10.1177/1354856507084422.

Eskola, Jari ja Juha Suoranta. 1998. Johdatus laadulliseen tutkimukseen. Tampere: Vastapaino.

Freedman, Des ja Vana Goblot. 2018. A future for public service television. Lontoo: Goldsmiths Press.

Gehman, Joel, Linda K. Treviño ja Raghu Garud. 2013. "Values Work: A Process Study of the Emergence and Performance of Organizational Values Practices." Academy of Management Journal 56 (1): 84-112. https://doi.org/10.5465/amj.2010.0628.

Gillespie, Tarleton. 2010. “The Politics of ‘Platforms.”' New Media Q Society 12 (3): 347-364. https://doi.org/10.1177/1461444809342738.

Gond, Jean-Pascal, Laure Cabantous, Nancy Harding ja Mark Learmonth. 2016. "What Do We Mean by Performativity in Organizational and Management Theory? The Uses and Abuses of Performativity." International Journal of Management Reviews 18 (4): 440-63. https://doi.org/10.1111/ijmr.12074.

Hanusch, Folker. 2016. "Web analytics and the functional differentiation of journalism cultures: Individual, organizational and platform-specific influences on newswork." Information, Communication Q Society 20 (10): 1571-1586. https://doi.org/10.1080/1369118X.2016.1241294.

Helberger, Natali. 2019. “On the democratic role of news recommenders." Digital Journalism 7 (8): 993-1012. https://doi.org/10.1080/21670811.2019.1623700.

Helberger, Natali. 2020. "The political power of platforms: How current attempts to regulate misinformation amplify opinion power." Digital Journalism 8 (6): 842-854. https://doi.org/10.1080/21670811.2020.1773888.

Helmond, Anne. 2015. "The Platformization of the Web: Making Web Data Platform Ready." Social Media + Society 1 (July-December 2015): 1-11. https://doi.org/10.1177/2056305115603080.

Hermida, Alfred. 2020. "Post-Publication Gatekeeping: The Interplay of Publics, Platforms, Paraphernalia, and Practices in the Circulation of News." Journalism and Mass Communication Quarterly 97(2): 469-491. https://doi.org/10.1177/1077699020911882.

Hokka, Jenni. 2017. “Making Public Service under Social Media Logics." International Journal of Digital Television 8 (2): 221-237. https://doi.org/10.1386/jdtv.8.2.221_1.

Hokka, Jenni. 2019. "Towards nuanced universality: Developing a concept bible for public service online news production." European Journal of Communication 34(1): 74-87. https://doi.org/10.1177/0267323118810862. 
Hölig, Sascha ja Uwe Hasebrink. 2018. Germany. Teoksessa Reuters Institute Digital News Report 2018, toimittaneet Nick Newman, Richard Fletcher, Antonis Kalogeropoulos, David Levy ja Rasmus Kleis Nielsen. Oxford: Reuters Institute for the Study of Journalism, University of Oxford.

Iosifidis, Petros. 2011. "The public sphere, social networks and public service media." Information, Communication Q Society 14 (5): 619-637. https://doi.org/10.1080/1369118X.2010.514356.

Jakubowicz, Karol. 2006. PSB: The beginning of the end, or a new beginning in the 21st Century? Teoksessa Proceedings of the third RIPE conference, Amsterdam, 16 November. Amsterdam: University of Amsterdam.

Juntunen, Laura. 2017. Kulttuurien törmäys? Journalismin etiikka sosiaalisen median aikakaudella. Helsinki: Viestinnän tutkimuskeskus CRC, Helsingin yliopisto.

Just, Natasch ja Michael Latzer. 2017. "Governance by Algorithms: Reality Construction by Algorithmic Selection on the Internet." Media, Culture Q Society 39 (2): 238-258. https://doi.org/10.1177/0163443716643157.

Keinonen, Heidi. 2015. "Televisio- ja tuotantoyhtiöiden haasteet ja mahdollisuudet monimediaalisessa ympäristössä." Media Q viestintä 38 (2): 57-73. https://doi.org/10.23983/mv.62095.

Keinonen, Heidi ja Oranit Klein Shagrir. 2017. “From public service broadcasting to soci(et)al TV: Producers' perceptions of interactivity and audience participation in Finland and Israel." Nordicom Review 38 (1): 65-79. https://doi.org/10.1515/nor-2016-0037.

Laaksonen, Salla-Maaria. 2020. "Viestinnän infrastruktuurit: Kuka päättää, mistä verkossa keskustellaan?" Teoksessa Kuka maailmaa hallitsee? Vallan umpisolmuja avaamassa. Tiedekulmapokkari 2, 105-120. Helsinki: Gaudeamus.

Laki Yleisradio Oy:stä 19.8.2005/635, 7 §: Julkinen palvelu. Luettu 20.11.2019. https://www.finlex.fi/fi/laki/ajantasa/1993/1993138o.

Larsen, Håkon. 2014. "The legitimacy of public service broadcasting in the 21st century: The case of Scandinavia." Nordicom Review 35 (2): 65-76. https://doi.org/10.2478/nor-2014-0015.

Lawrence, Regina G., Damian Radcliffe ja Thomas R. Schmidt. 2018. "Practicing engagement: Participatory journalism in the Web 2.0 era." Journalism Practice 12 (10): 1220-1240. https://doi.org/10.1080/17512786.2017.1391712.

Lehtisaari, Katja, Mikko Villi, Mikko Grönlund, Carl-Gustav Lindén, Bozena I. Mierzejewska, Robert Picard ja Axel Roepnack. 2018. "Comparing Innovation and Social Media Strategies in Scandinavian and US Newspapers." Digital Journalism 6 (8): 1029-1040. https://doi.org/10.1080/21670811.2018.1503061.

Lowe, Gregory Ferrell. 2010. "Mutkainen taival kohti julkisen palvelun mediaa." Teoksessa Yleisradio median murroksessa, toimittaneet Airi Leppänen, Timo-Erkki Heino ja Eeva Mäntymäki, 25-42. Tampere: Vastapaino.

Malmelin, Nando ja Mikko Villi. 2017. "Media work in change: Understanding the role of media professionals is times of digital transformation and convergence." Sociology Compass 11 (17): 1-9. https://doi.org/10.1111/soc4.12494.

Meese, James ja Edward Hurcombe. 2020. "Facebook, News Media and Platform Dependency: The Institutional Impacts of News Distribution on Social Platforms." New Media Q Society, June. https://doi.org/10.1177/1461444820926472.

Meyer, John C. 1995. "Tell Me a Story: Eliciting Organizational Values from Narratives." Communication Quarterly 43 (2): 210-24. https://doi.org/10.1080/01463379509369970.

Moe, Hallvard. 2013. "Public service broadcasting and social networking sites: The Norwegian broadcasting corporation on Facebook." Media International Australia 146 (1): 114-122. https://doi.org/10.1177/1329878X1314600115.

Neheli, Nicole Blanchett. 2018. "News by Numbers. The evolution of analytics in journalism." Digital Journalism 6 (8): 1041-1051. https://doi.org/10.1080/21670811.2018.1504626.

Newman, Nic. 2020. Executive summary and key findings of the 2020 report. Oxford: Reuters Institute for the Study of Journalism. Luettu 7.10.2020. http://www.digitalnewsreport.org/survey/2020/overview-key-findings-2020/.

Nieborg, David ja Thomas Poell. 2018. "The platformization of cultural production: Theorizing the contingent cultural commodity." New Media Q Society 20 (11): 4275-4292. https://doi.org/10.1177/1461444818769694.

Nieborg, David ja Thomas Poell. 2019. "The platformization of making media." Teoksessa Making Media: Production, Practices, and Professions, toimittaneet Mark Deuze ja Mirjam Prenger, 85-96. Amsterdam: Amsterdam University Press.

Nielsen, Rasmus Kleis ja Sarah Anne Ganter. 2018. "Dealing with digital intermediaries: A case study of the relations between publishers and platforms." New Media Q Society 20 (4): 1600-1617. https://doi.org/10.1177/1461444817701318. 
Nikunen, Kaarina ja Jenni Hokka. 2020. "Welfare State Values and Public Service Media in the Era of Datafication.” Global Perspectives 1 (1). https://doi.org/10.1525/gp.2020.12906.

Plantin, Jean Christophe ja Aswin Punathambekar. 2019. "Digital Media Infrastructures: Pipes, Platforms, and Politics." Media, Culture and Society 41 (2): 163-74. https://doi.org/10.1177/0163443718818376.

Pruzan, Peter. 2001. "The Question of Organizational Consciousness: Can Organizations Have Values, Virtues and Visions?" Journal of Business Ethics 29 (3): 271-84. https://doi.org/10.1023/A:1026577604845.

Rashidian, Nushin, Pete Brown, Elizabeth Hansen, Emily Bell, Jonathan Albright ja Abigail Hartstone. 2019. Friend Q Foe: The Platform Press at the Heart of Journalism. Columbia Journalism School: Tow Center for Digital Journalism.

Reunanen, Esa. 2020. Uutismedia Verkossa 2020. Reuters-instituutin Digital News Report - Suomen Maaraportti. Tampere: Tampereen yliopisto.https://trepo.tuni.fi/handle/10024/122596.

Rotermund, Hermann. 2018. "Digital Media Culture and Public Service Media in the Platform Era." Teoksessa Public Service Media in the Networked Society, toimittaneet Gregory Ferrell Lowe, Hilde Van den Bulck ja Karen Donders, 75-89. Göteborg: Nordicom.

Schein, Edgar H. 1985. Organizational culture and leadership. San Francisco: Jossey-Bass.

Schulz, Anne, David A. L. Levy ja Rasmus Kleis Nielsen. 2019. Old, educated, and politically diverse: The audience of public service news. Oxford: Reuters Institute for the Study of Journalism.

Sehl, Annika, Alessio Cornia ja Rasmus Kleis Nielsen. 2018. Public Service News and Social Media. Oxford University: Reuters Institute for the Study of Journalism.

Sehl, Annika, Alessio Cornia ja Rasmus Kleis Nielsen. 2016. Public Service News and Digital Media. Oxford University: Reuters Institute for the Study of Journalism.

Sehl, Annika, Alessio Cornia, Lucas Graves ja Rasmus Kleis Nielsen. 2019. “Newsroom integration as an organizational challenge: Approaches of European public service media from a comparative perspective." Journalism Studies 20 (9): 1238-1259. https://doi.org/10.1080/1461670X.2018.1507684.

Sehl, Annika, Richard Fletcher ja Robert G. Picard. 2020. "Crowding out: Is there evidence that public service media harm markets? A cross-national comparative analysis of commercial television and online news providers." European Journal of Communication 35 (4): 389-409. https://doi.org/10.1177/0267323120903688.

Tracy, Sarah J. 2013. Qualitative research methods: Collecting evidence, crafting analysis, communicating impact. Chichester: Wiley-Blackwell.

Tuomi, Jouni ja Anneli Sarajärvi. 2009. Laadullinen tutkimus ja sisällönanalyysi (6. uud. laitos.). Helsinki: Tammi.

Van den Bulck, Hilde ja Hallvard Moe. 2018. "Public service media, universality and personalisation through algorithms: Mapping strategies and exploring dilemmas." Media, Culture Q Society 40 (6): 875-892. https://doi.org/10.1177/0163443717734407.

Van Dijck, José. 2013. The culture of connectivity: A critical history of social media. Oxford: Oxford University Press.

Van Dijck, José ja Thomas Poell. 2013. "Understanding Social Media Logic.” Media and Communication 1 (1): 2-14. https://doi.org/10.17645/mac.v1i1.70.

Van Dijck, José, Thomas Poell ja Martijn de Waal. 2018. The platform society: Public values in a connective world. New York: Oxford University Press.

Yle. 2017. Ylen strategia. Luettu 30.3.2020. https://yle.fi/aihe/artikkeli/2017/10/24/ylen-strategia.

Yle. 2020. Ylen strategia: Kaikille yhteinen, jokaiselle oma. Luettu 23.5.2020. https://yle.fi/aihe/strategia.

Zamith, Rodrigo. 2018. "Quantified Audiences in News Production: A Synthesis and Research Agenda." Digital Journalism 6 (4): 418-435. https://doi.org/10.1080/21670811.2018.1444999. 